\title{
Dyella soli sp. nov. and Dyella terrae sp. nov., isolated from soil
}

\section{Correspondence Soon-Wo Kwon swkwon@rda.go.kr}

\author{
Hang-Yeon Weon, ${ }^{1}$ Rangasamy Anandham, ${ }^{2}$ Byung-Yong Kim, ${ }^{3}$ \\ Seung-Beom Hong, ${ }^{3}$ Young-Ah Jeon ${ }^{3}$ and Soon-Wo Kwon ${ }^{3}$
}

\author{
${ }^{1}$ Applied Microbiology Division, National Institute of Agricultural Science and Technology, Rural \\ Development Administration (RDA), Suwon 441-707, Republic of Korea \\ ${ }^{2}$ Organic Farming Division, National Institute of Agricultural Science and Technology, Rural \\ Development Administration (RDA), Suwon 441-707, Republic of Korea \\ ${ }^{3}$ Korean Agricultural Culture Collection (KACC), Microbial Genetics Division, National Institute of \\ Agricultural Biotechnology, RDA, Suwon 441-707, Republic of Korea
}

Xie \& Yokota (2005) isolated three bacterial strains from garden soil and assigned them to a novel genus, Dyella, with Dyella japonica as the type species. Members of the genus Dyella are yellow-coloured rods that are catalaseand oxidase-positive and urease-negative. These yellowpigmented strains were shown to be distinguished from other genera, as represented by Frateuria aurantia (Swings et al., 1980), Rhodanobacter lindaniclasticus (Nalin et al., 1999), Fulvimonas soli (Mergaert et al., 2002) and Luteibacter rhizovicinus (Johansen et al., 2005), based on $16 \mathrm{~S}$ rRNA gene sequences. In addition, the genus Dyella can be differentiated from Frateuria aurantia by the absence of cellular fatty acids $\mathrm{C}_{12: 0} 2-\mathrm{OH}, \mathrm{C}_{12: 0} 3-\mathrm{OH}$, $\mathrm{C}_{18: 0}$ and $\mathrm{C}_{17: 0}$ cyclo in Dyella species and from Fulvimonas soli on the basis of $\mathrm{G}+\mathrm{C}$ content (63-67 compared with $71.7 \mathrm{~mol} \%$ for Fulvimonas soli). At present,

Abbreviations: DIG, digoxigenin-11-dUTP; ML, maximum-likelihood; $\mathrm{MP}$, maximum-parsimony; $\mathrm{NJ}$, neighbour-joining.

The GenBank/EMBL/DDBJ accession numbers for the 16S rRNA gene sequences of strains JS12-10 ${ }^{\top}$ and $J S 14-6^{\top}$ are EU604272 and EU604273, respectively.

Maximum-likelihood and maximum-parsimony trees based on 16S rRNA gene sequences are available with the online version of this paper. the genus Dyella includes five species, namely $D$. japonica (Xie \& Yokota, 2005), D. koreensis (An et al., 2005), D. yeojuensis (Kim et al., 2006), D. ginsengisoli (Jung et al., 2009) and D. marensis (Lee \& Lee, 2009).

During a survey on cultivable bacterial communities, we isolated two yellow-coloured strains, JS12-10 ${ }^{\mathrm{T}}$ and JS14- $6^{\mathrm{T}}$, from forest soil and soil cultivated with Citrus species, respectively, taken from Jeju island, Republic of Korea. These two strains were shown to be affiliated with the genus Dyella of the order Xanthomonadales and subjected to further taxonomic characterization. The results from phenotypic, chemotaxonomic and phylogenetic analyses, in combination with DNA-DNA hybridization experiments, showed the distinctiveness of strains JS12-10 $0^{\mathrm{T}}$ and JS14- ${ }^{\mathrm{T}}$, both from each other and from the type strains of species of Dyella.

Soil samples ( $1 \mathrm{~g}$ ) were suspended in $9 \mathrm{ml} 0.85 \% \mathrm{NaCl}$ (w/ v) solution and mixed in a shaker for $30 \mathrm{~min}$. Aliquots of the serially diluted sample were spread on R2A agar plates (Reasoner \& Geldreich, 1985) and incubated at $28{ }^{\circ} \mathrm{C}$ for 5 days. Strains JS12-10 $0^{\mathrm{T}}$ and JS14- $6^{\mathrm{T}}$, which could be distinguished by their yellow-coloured colonies, were cultured and maintained on R2A agar at $28{ }^{\circ} \mathrm{C}$ and were 
subjected to taxonomic investigation. D. japonica DSM $16301^{\mathrm{T}}$, D. koreensis KCTC $12359^{\mathrm{T}}$, D. yeojuensis KACC $11405^{\mathrm{T}}$, Frateuria aurantia DSM $6220^{\mathrm{T}}$ and L. rhizovicinus KACC $12830^{\mathrm{T}}$ were used as reference strains in biochemical, chemotaxonomic and DNA-DNA hybridization experiments. To investigate basic morphological, physiological and biochemical characteristics, the methods described by Smibert \& Krieg (1994) were used for Gram staining, oxidase and catalase reactions and to test for hydrolysis of CM-cellulose, casein, chitin, DNA, pectin, starch, tyrosine, Tween 80 and xanthine. R2A medium was used to determine growth at various temperatures $\left(5-45{ }^{\circ} \mathrm{C}\right.$ at intervals of $\left.5{ }^{\circ} \mathrm{C}\right)$ and requirement for $\mathrm{NaCl}$ $(0-5 \%, w / v)$. The $\mathrm{pH}$ range for growth $(\mathrm{pH} 4-10$ at intervals of $1 \mathrm{pH}$ unit) was determined in R2A broth adjusted with citrate-phosphate buffer or Tris/ $\mathrm{HCl}$ buffer (Breznak \& Costilow, 1994). Cell morphology was observed by transmission electron microscopy (model 912AB; LEO) and phase-contrast microscopy (Axio; Zeiss). For observation of cell morphology by TEM, cells were grown on R2A agar and suspended in physiological saline solution. A small drop of the suspension was placed on a carbon-coated copper grid and the cells were negatively stained with $0.5 \%$ uranyl acetate. For other phenotypic tests, API 20 NE, ID 32 GN and API ZYM test kits (bioMérieux) were used according to the manufacturer's recommendations. The API ZYM tests were read after $4 \mathrm{~h}$ incubation at $37^{\circ} \mathrm{C}$, the other API tests after 5 days at $28{ }^{\circ} \mathrm{C}$. Whole-cell fatty acids were analysed according to the standard protocol of the MIDI/Hewlett Packard Microbial Identification System (Sasser, 1990) after cultivation on R2A agar for 2 days at $28{ }^{\circ} \mathrm{C}$.

Genomic DNA was isolated and purified following the method described by Ausubel et al. (1987). The 16S rRNA gene sequence was amplified by using the universal primers fD1 and rP2 (Weisburg et al., 1991) and sequenced as described by Weon et al. (2005) with an automatic DNA sequencer (ABI 3100; Applied Biosystems). The 16S rRNA gene sequences were aligned with the CLUSTAL $\mathrm{W}$ program (Thompson et al., 1994). Evolutionary distances were calculated using Kimura's two-parameter model (Kimura, 1983). Phylogenetic trees were constructed with neighbour-joining (Saitou \& Nei, 1987), maximum-parsimony (Fitch, 1971) and maximum-likelihood (Felsenstein, 1981) methods using the program MEGA3 (Kumar et al., 2004) and bootstrap values were calculated on the basis of 1000 replications (Felsenstein, 1985).

DNA-DNA hybridization experiments were performed using reagents from Roche Diagnostics according to the manufacturer's instructions, as follows. Chromosomal DNA of strains JS12-10 $0^{\mathrm{T}}$ and JS14- $6^{\mathrm{T}}$, type strains of species of the genus Dyella and Frateuria aurantia DSM $6220^{\mathrm{T}}$ were used to construct hybridization probes by labelling with digoxigenin-11-dUTP (DIG). DNA samples from strains $J S 12-10^{\mathrm{T}}$ and $J S 14-6^{\mathrm{T}}$ were loaded on to positively charged membranes as described by Seldin \& Dubnau (1985). Pre-hybridization and hybridization con- ditions for the DIG-labelled probes were as described for the DIG High Prime DNA Labeling and Detection Starter kit II. After hybridization, the blots were subjected to stringent washing steps, after which the chemiluminescence detection kit, based on CSPD, was used. Levels of relatedness were determined by scanning the X-ray membranes and slot intensities were determined by using the 1D Image Analysis Software version 3.0 (Kodak Digital Science). Self-hybridization values were considered to represent $100 \%$ of the maximal achievable signal and values obtained with the other strains were compared with this standard. The experiments were carried out in triplicate for each sample. $\mathrm{G}+\mathrm{C}$ contents were determined by HPLC analysis of deoxyribonucleosides as described by Mesbah et al. (1989), using a reversed-phase column (Supelcosil LC-18 S; Supelco).

Strains JS12-10 ${ }^{\mathrm{T}}$ and JS14- ${ }^{\mathrm{T}}$ were Gram-negative, aerobic, rod-shaped and motile with one flagellum. Both grew well on R2A agar, nutrient agar and tryptic soy agar (Difco). Strain JS14 $-6^{\mathrm{T}}$ grew on MacConkey agar (Difco) but strain JS12- $10^{\mathrm{T}}$ did not. The strains could be differentiated from each other on the basis of DNA hydrolysis, nitrate reduction, arginine hydrolysis, assimilation of carbon compounds and enzyme activities. Also, the two strains could be separated from other members of genus Dyella, Frateuria aurantia and L. rhizovicinus on the basis of phenotypic properties (Table 1).

For the 16S rRNA gene sequence analysis, continuous stretches of $1420 \mathrm{bp}$ (strain JS12-10 ${ }^{\mathrm{T}}$ ) and $1423 \mathrm{bp}$ (JS14$6^{\mathrm{T}}$ ) were obtained and analysed. Strain JS12-10 ${ }^{\mathrm{T}}$ showed the highest sequence similarities to $D$. ginsengisoli Gsoil $3046^{\mathrm{T}}(98.4 \%)$ and D. koreensis BB4 ${ }^{\mathrm{T}}(98.1 \%)$, followed by D. japonica $\mathrm{XD}^{\mathrm{T}}{ }^{\mathrm{T}}(97.9 \%)$, Frateuria aurantia DSM $6220^{\mathrm{T}}(97.5 \%)$, D. marensis CS5-B2 ${ }^{\mathrm{T}}(97.2 \%)$, strain JS14$6^{\mathrm{T}}(97.1 \%)$ and D. yeojuensis R2A16-10 $10^{\mathrm{T}}(96.1 \%)$. Strain JS14-6 ${ }^{\mathrm{T}}$ showed high sequence similarities to $D$. japonica $\mathrm{XD}^{\mathrm{T}}{ }^{\mathrm{T}}(97.9 \%)$, D. ginsengisoli Gsoil $3046^{\mathrm{T}}(97.3 \%), D$. marensis CS5-B2 ${ }^{\mathrm{T}}(97.2 \%)$, strain JS12-10 ${ }^{\mathrm{T}}(97.1 \%), D$. koreensis $\mathrm{BB}^{\mathrm{T}}$ (96.8\%), D. yeojuensis $\mathrm{R} 2 \mathrm{~A} 16-10^{\mathrm{T}}$ (96.7\%) and Frateuria aurantia DSM $6220^{\mathrm{T}}(96.7 \%)$. Evolutionary trees based on $16 \mathrm{~S}$ rRNA gene sequences were constructed with the neighbour-joining (NJ), maximum-parsimony (MP) and maximum-likelihood (ML) methods (Fig. 1 and Supplementary Fig. S1, available in IJSEM Online). The overall topologies of the phylogenetic trees were similar irrespective of the phylogenetic methods used. The phylogenetic analysis revealed that the genus Dyella is polyphyletic and that the 16S rRNA gene sequence from Frateuria aurantia DSM $6220^{\mathrm{T}}$ is similar to those of the Dyella species (Fig. 1). This anomaly can be explained by the high evolutionary rate of the $16 \mathrm{~S}$ rRNA gene, meaning that multiple substitutions often occur at the same nucleotide position. This implies that there has been mutational saturation of 16S rRNA gene nucleotide sequences, which is known to confuse phylogenetic inference (Leblond-Bourget et al., 1996; Dauga, 2002). This phenomenon was obvious when the addition of the 
Table 1. Differential phenotypic characteristics of strains $J S 12-10^{\top}$ and $J S 14-6^{\top}$ and type strains of related species

Strains: 1 , Dyella soli sp. nov. JS12-10 ${ }^{\mathrm{T}} ; 2$, Dyella terrae sp. nov. JS14-6 ${ }^{\mathrm{T}} ; 3$, D. yeojuensis KACC $11405^{\mathrm{T}} ; 4$, D. japonica DSM 16301 ${ }^{\mathrm{T}}$; 5 , D. koreensis KCTC $12359^{\mathrm{T}}$; 6, D. ginsengisoli Gsoil $3046^{\mathrm{T}} ; 7$, D. marensis CS5-B2 ${ }^{\mathrm{T}} ; 8$, Frateuria aurantia DSM $6220^{\mathrm{T}}$; 9, Luteibacter rhizovicinus KACC $12830^{\mathrm{T}}$. Unless indicated otherwise, data were obtained in this study (columns 1, 2 and 9) or taken from Kim et al. (2006) (columns 3-5 and 8), Jung et al. (2009) (column 6) and Lee \& Lee (2009) (column 7). All strains are positive for alkaline phosphatase, esterase lipase (C8), leucine arylamidase, valine arylamidase and naphthol-AS-BI-phosphohydrolase (except D. ginsengisoli Gsoil $3046^{\mathrm{T}}$; data not available) and assimilate D-glucose. All strains are negative for indole production, urease, lipase (C14), trypsin, $\beta$-glucuronidase and $\alpha$-mannosidase (except $D$. ginsengisoli Gsoil $3046^{\mathrm{T}}$; data not available) and do not assimilate L-arabinose, D-mannitol, potassium gluconate, capric acid, adipic acid, trisodium citrate or phenylacetic acid. +, Positive; (+), weakly positive; -, negative; ND, not detected/not reported.

\begin{tabular}{|c|c|c|c|c|c|c|c|c|c|}
\hline Characteristic & 1 & 2 & 3 & 4 & 5 & 6 & 7 & 8 & 9 \\
\hline Catalase/oxidase & $+1+$ & $+/+$ & $+1+$ & $-1+$ & $+/(+)$ & $+1+$ & $+1-$ & $-1+$ & $+1+^{*}$ \\
\hline Motility & + & + & + & + & - & + & + & + & $+^{*}$ \\
\hline $4 \% \mathrm{NaCl}$ & - & - & + & - & $(+)$ & - & - & - & $-*$ \\
\hline $\mathrm{pH} 4.5$ & + & + & - & - & $\mathrm{ND}$ & - & - & + & $-*$ \\
\hline \multicolumn{10}{|l|}{ Hydrolysis of: } \\
\hline CM-cellulose & - & - & - & - & + & - & - & - & $\mathrm{ND}$ \\
\hline DNA & - & + & + & + & + & - & + & + & $+^{*}$ \\
\hline Starch & - & - & - & - & - & + & + & - & $+^{*}$ \\
\hline \multicolumn{10}{|l|}{ Acid production from: } \\
\hline Arabinose & - & - & - & + & + & - & - & + & $\mathrm{ND}$ \\
\hline Glucose & - & - & + & + & + & + & + & + & - \\
\hline Glucose fermentation & - & - & - & - & - & + & + & + & $(+)$ \\
\hline Arginine dihydrolase & + & - & - & - & - & $\mathrm{ND}$ & - & - & - \\
\hline Aesculin hydrolysis & - & - & + & - & + & $\mathrm{ND}$ & ND & - & + \\
\hline Gelatin hydrolysis & - & - & + & - & + & + & + & - & + \\
\hline$\beta$-Galactosidase & - & $(+)$ & + & - & + & $\mathrm{ND}$ & + & - & + \\
\hline \multicolumn{10}{|l|}{ Assimilation of: (API 20NE) } \\
\hline$N$-Acetylglucosamine & + & + & + & + & + & + & + & - & + \\
\hline Malic acid & - & - & - & - & + & - & + & - & - \\
\hline Maltose & + & + & + & + & + & + & + & - & + \\
\hline D-Mannose & - & + & + & + & + & - & + & - & + \\
\hline \multicolumn{10}{|l|}{ Enzyme activity (API ZYM) } \\
\hline$\beta$-Glucosidase & + & - & + & + & + & $\mathrm{ND}$ & + & - & + \\
\hline$N$-Acetyl- $\beta$-glucosaminidase & + & - & + & - & + & $\mathrm{ND}$ & - & - & - \\
\hline DNA G $+\mathrm{C}$ content $(\mathrm{mol} \%)$ & 67.0 & 64.0 & 63.0 & 63.5 & 63.8 & 66.6 & 66.2 & 63.5 & 64.3 \\
\hline
\end{tabular}

${ }^{\star}$ Data from Johansen et al. (2005).

sequence from D. yeojuensis $\mathrm{R} 2 \mathrm{~A} 16-10^{\mathrm{T}}$ resulted in bifurcation of the genus Dyella. Horizontal gene transfer may explain some of the discrepancies between the defined phylogenetic clusters and the groups described by phenotypic data (Dauga, 2002). However, as far as is known to date, there is no report of horizontal gene transfer between Dyella species and Frateuria aurantia. The sequence from strain JS12-10 ${ }^{\mathrm{T}}$ clustered with that from D. ginsengisoli Gsoil $3046^{\mathrm{T}}$ and the sequence from strain JS14- $6^{\mathrm{T}}$ clustered with that from D. japonica XD53 ${ }^{\mathrm{T}}$ (with bootstrap values of 


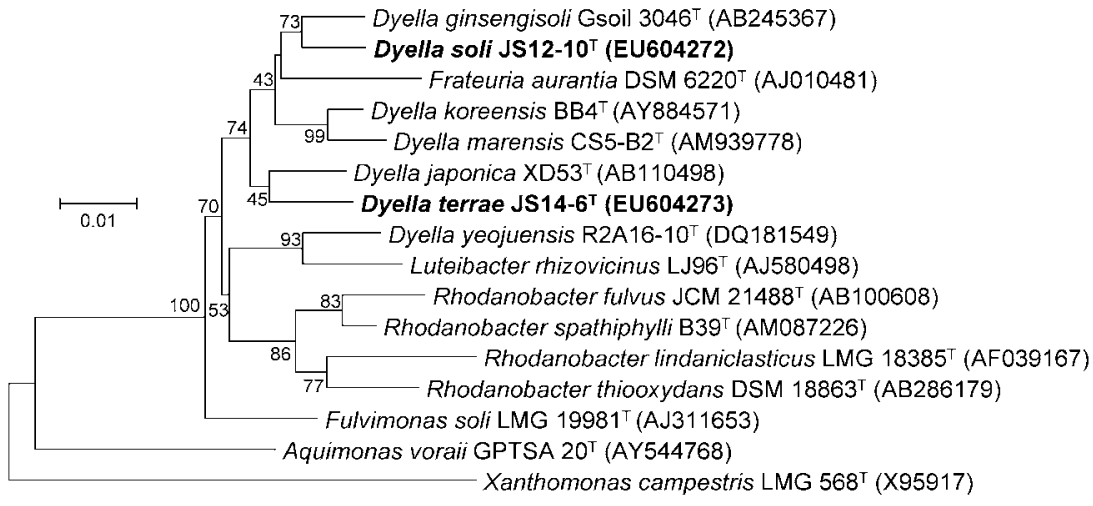

Fig. 1. Neighbour-joining tree based on almost-complete 16S rRNA gene sequences showing the phylogenetic position of strains $\mathrm{JS} 12-10^{\top}$ and $\mathrm{JS} 14-6^{\top}$. Numbers at nodes ( $>40 \%$ ) indicate percentages of 1000 bootstrap resamplings. The outgroup is Xanthomonas campestris LMG $568^{\top}$. Bar, 0.01 substitutions per nucleotide position.
73, 79 and $53 \%$ and 45,52 and $20 \%$ for the NJ, ML and MP trees, respectively). The bootstrap values of the nodes of the few clusters obtained were too low to induce much confidence and indicate that the $16 \mathrm{~S}$ rRNA gene sequence alone cannot resolve the phylogenetic relationship among the genera Dyella, Frateuria, Fulvimonas and Luteibacter (Dauga, 2002). The NJ, ML and MP trees placed the sequence from Frateuria aurantia DSM $6220^{\mathrm{T}}$ within the cluster for Dyella species, which is in complete disagreement with phenotypic and fatty acid data (Tables 1 and 2). Fatty acid profiles, $\mathrm{G}+\mathrm{C}$ contents and phenotypic properties may be used to differentiate these genera.

The major fatty acids ( $>10 \%)$ of strain JS12-10 ${ }^{\mathrm{T}}$ were iso$\mathrm{C}_{17: 1} \omega 9 c(24.2 \%)$, iso- $\mathrm{C}_{15: 0}(19.9 \%)$ and iso- $\mathrm{C}_{16: 0}$ $(17.8 \%)$ and the major fatty acids of strain JS14- $6^{\mathrm{T}}$ were

Table 2. Cellular fatty acid compositions of strains $J S 12-10^{\top}$ and $J S 14-6^{\top}$ and type strains of closely related species

Strains: 1, D. soli sp. nov. JS12-10 ${ }^{\mathrm{T}} ; 2$, D. terrae sp. nov. JS14-6 ${ }^{\mathrm{T}} ; 3$, D. yeojuensis KACC $11405^{\mathrm{T}} ; 4$, D. japonica DSM $16301^{\mathrm{T}} ; 5$, D. koreensis KCTC $12359^{\mathrm{T}} ; 6$, D. ginsengisoli Gsoil $3046^{\mathrm{T}} ; 7$, Frateuria aurantia DSM $6220^{\mathrm{T}} ; 8$, Luteibacter rhizovicinus KACC $12830^{\mathrm{T}}$. Data were obtained in this study (columns 1, 2 and 8) or were taken from Kim et al. (2006) (columns 3-5 and 7) and Jung et al. (2009) (column 6). All data were collected from cultures after 2 days on R2A agar at $28{ }^{\circ} \mathrm{C}$. - , Not detected or $<1 \%$.

\begin{tabular}{|c|c|c|c|c|c|c|c|c|}
\hline Fatty acid & 1 & 2 & 3 & 4 & 5 & 6 & 7 & 8 \\
\hline iso- $\mathrm{C}_{11: 0}$ & 3.4 & 3.8 & 3.7 & 5.0 & 4.5 & 4.9 & - & 3.8 \\
\hline iso- $\mathrm{C}_{11: 0} 3-\mathrm{OH}$ & 3.8 & 5.2 & 4.2 & 6.0 & 5.5 & 4.0 & - & 3.4 \\
\hline $\mathrm{C}_{12: 0} 2-\mathrm{OH}$ & - & - & - & - & - & - & 2.2 & - \\
\hline $\mathrm{C}_{12: 0} 3-\mathrm{OH}$ & - & - & - & - & - & - & 5.7 & - \\
\hline iso- $\mathrm{C}_{12: 0} 3-\mathrm{OH}$ & - & 1.6 & 1.0 & 1.4 & 1.4 & - & - & - \\
\hline iso- $\mathrm{C}_{13: 0} 3-\mathrm{OH}$ & 2.6 & 2.8 & 2.4 & 4.0 & 2.3 & 2.8 & 1.2 & 2.6 \\
\hline $\mathrm{C}_{14: 0}$ & - & - & - & - & - & - & 3.1 & - \\
\hline $\mathrm{C}_{14: 1} \omega 5 c$ & - & - & - & - & - & - & 1.0 & - \\
\hline iso- $\mathrm{C}_{14: 0}$ & - & 1.2 & 1.1 & - & 1.1 & - & - & 1.4 \\
\hline anteiso- $C_{15: 0}$ & 4.9 & 3.1 & 6.9 & 5.1 & 3.6 & 4.1 & 2.4 & 8.8 \\
\hline iso- $\mathrm{C}_{15: 0}$ & 19.9 & 18.2 & 14.5 & 14.6 & 11.1 & 14.6 & 41.2 & 25.4 \\
\hline $\mathrm{C}_{16: 0}$ & 1.9 & 1.8 & 1.8 & 1.5 & 2.5 & 3.4 & 7.5 & 8.8 \\
\hline iso- $\mathrm{C}_{16: 0}$ & 17.8 & 21.6 & 21.3 & 17.5 & 19.2 & 5.1 & - & 8.4 \\
\hline iso- $\mathrm{C}_{16: 1} \mathrm{H}$ & 1.1 & 1.1 & - & - & - & - & - & - \\
\hline $\mathrm{C}_{17: 0}$ cyclo & - & - & - & - & - & - & 9.8 & 8.3 \\
\hline $\mathrm{C}_{17: 1} \omega 6 c$ & - & 1.4 & - & - & - & - & - & - \\
\hline anteiso- $\mathrm{C}_{17: 0}$ & 1.8 & 1.1 & 1.6 & 1.8 & 2.9 & 0.8 & - & - \\
\hline iso- $\mathrm{C}_{17: 0}$ & 8.3 & 5.0 & 7.9 & 8.5 & 6.7 & 29.2 & 5.3 & 8.8 \\
\hline iso- $\mathrm{C}_{17: 0} 3-\mathrm{OH}$ & - & - & - & 1.5 & - & - & - & - \\
\hline iso- $\mathrm{C}_{17: 1} \omega 9 c$ & 24.2 & 18.9 & 21.5 & 20.3 & 19.0 & 28.2 & 1.8 & 8.8 \\
\hline $\mathrm{C}_{18: 0}$ & - & - & - & - & - & - & 1.2 & - \\
\hline iso- $\mathrm{C}_{18: 0}$ & - & 1.0 & 1.2 & 1.3 & 2.6 & - & - & - \\
\hline Unknown 11.799 & 2.0 & 2.6 & 2.3 & 3.1 & 2.5 & 1.1 & - & 2.0 \\
\hline Summed feature $3^{*}$ & 4.2 & 8.5 & 5.2 & 5.0 & 7.9 & 2.0 & 10.5 & 6.6 \\
\hline
\end{tabular}

${ }^{*}$ Summed feature 3 contains iso- $\mathrm{C}_{15: 0} 2-\mathrm{OH}$ and/or $\mathrm{C}_{16: 1} \omega 7 c$. 
iso- $\mathrm{C}_{16: 0}(21.6 \%)$, iso- $\mathrm{C}_{17: 1} \omega 9 c(18.9 \%)$ and iso- $\mathrm{C}_{15: 0}$ $(18.2 \%)$ (Table 2). The fatty acid profiles of the Dyella species and the novel isolates differed from Frateuria aurantia DSM $6220^{\mathrm{T}}$ and L. rhizovicinus KACC $12830^{\mathrm{T}}$ in the absence of $\mathrm{C}_{17: 0}$ cyclo, $\mathrm{C}_{12: 0} 2-\mathrm{OH}, \mathrm{C}_{12: 0} 3-\mathrm{OH}, \mathrm{C}_{14: 0}$ and $\mathrm{C}_{14: 1} \omega 5 c$, the presence of anteiso- $\mathrm{C}_{17: 0}$ and a larger proportion of iso- $C_{17: 1} \omega 9 c$. Strains JS12-10 ${ }^{\mathrm{T}}$ and JS14- ${ }^{\mathrm{T}}$ could be differentiated from the other strains tested on the basis of the presence of iso- $\mathrm{C}_{16: 1} \mathrm{H}$ in the novel isolates. Strain JS14-6 ${ }^{\mathrm{T}}$ contained iso- $\mathrm{C}_{12: 0}$ 3-OH, iso- $\mathrm{C}_{14: 0}$,

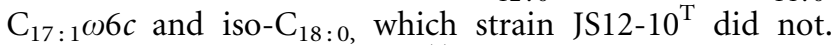
Only D. japonica DSM $16301^{\mathrm{T}}$ contained iso- $\mathrm{C}_{17: 0} 3-\mathrm{OH}$ and D. ginsengisoli Gsoil $3046^{\mathrm{T}}$ contained a larger percentage of iso- $\mathrm{C}_{17: 0}$ than the other strains tested.

The DNA G + C contents of strains JS12- $10^{\mathrm{T}}(67.0 \mathrm{~mol} \%)$ and JS14- $6^{\mathrm{T}}(64.0 \mathrm{~mol} \%)$ are close to the $\mathrm{G}+\mathrm{C}$ contents reported for $D$. ginsengisoli $(66.6 \mathrm{~mol} \%), D$. marensis (65.7-66.7 mol\%), D. japonica (63.4-64.0 mol\%) and D. koreensis $(63.8 \mathrm{~mol} \%)$. The DNA-DNA hybridization values for strain $\mathrm{JS} 12-10^{\mathrm{T}}$ with respect to $D$. koreensis KCTC $12359^{\mathrm{T}}$, D. japonica DSM $16301^{\mathrm{T}}$, strain JS14- $6^{\mathrm{T}}$ and Frateuria aurantia DSM $6220^{\mathrm{T}}$ were $35,32,29$ and $26 \%$, respectively. The levels of DNA-DNA relatedness for strain JS14-6 ${ }^{\mathrm{T}}$ with respect to D. japonica DSM $16301^{\mathrm{T}}$, D. yeojuensis KACC $11405^{\mathrm{T}}$, strain JS12-10 $10^{\mathrm{T}}$ and Frateuria aurantia DSM $6220^{\mathrm{T}}$ were $38,30,30$ and $26 \%$, respectively. DNA-DNA hybridization results revealed that strains JS12$10^{\mathrm{T}}$ and JS14- $6^{\mathrm{T}}$ were genotypically distant from each other and the type strains of Dyella and Frateuria. A bacterium that shows a 16S rRNA gene sequence similarity of $98 \%$ or below to its closest relatives is generally considered to belong to a different species, and this relatively low level of similarity usually indicates that the DNA-DNA reassociation level is lower than $50 \%$ (Wayne et al., 1987).

On the basis of the data from polyphasic studies, including analyses of biochemical properties, fatty acid composition, $16 \mathrm{~S}$ rRNA gene sequences and DNA-DNA hybridization values, it is shown that strains JS12-10 ${ }^{\mathrm{T}}$ and JS14- $6^{\mathrm{T}}$ represent two novel species within the genus Dyella, for which the names Dyella soli sp. nov. and Dyella terrae sp. nov., respectively, are proposed.

\section{Description of Dyella soli sp. nov.}

Dyella soli (so'li. L. gen. n. soli of soil).

Cells are Gram-negative, aerobic, rod-shaped, 0.4-0.5 $\mu \mathrm{m}$ wide and $0.9-5.0 \mu \mathrm{m}$ long, and motile with one polar flagellum. After growth on R2A medium at $28{ }^{\circ} \mathrm{C}$ for 2 days, colonies are yellow and irregular. Grows well on R2A agar, nutrient agar and tryptic soy agar and does not grow on MacConkey agar. Positive for nitrate reduction and methyl red tests and negative for Voges-Proskauer test, $\mathrm{H}_{2} \mathrm{~S}$ production and phenylalanine deaminase. Grows at 10-35 ${ }^{\circ} \mathrm{C}$ (optimum $28-30{ }^{\circ} \mathrm{C}$ ), $\mathrm{pH} 4-8$ (optimum pH 6-

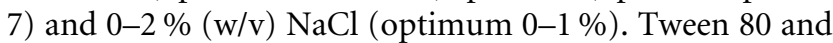
tyrosine are hydrolysed, but casein, chitin, CM-cellulose, DNA, pectin, starch and xanthine are not. Positive for arginine dihydrolase, but negative for indole production, glucose fermentation, urease, aesculin hydrolysis, gelatin hydrolysis and $\beta$-galactosidase (API 20NE). In addition to the data shown in Table 1 , sodium acetate is weakly assimilated but L-rhamnose, D-ribose, inositol, sucrose, itaconic acid, suberic acid, sodium malonate, lactic acid, Lalanine, potassium 5-ketogluconate, glycogen, 3-hydroxybenzoic acid, L-serine, salicin, melibiose, L-fucose, Dsorbitol, propionic acid, valeric acid, L-histidine, potassium 2-ketogluconate, 3-hydroxybutyric acid, 4-hydroxybenzoic acid and L-proline are not assimilated (API ID $32 \mathrm{GN}$ ). Major fatty acids $(>5 \%)$ are iso- $\mathrm{C}_{17: 1} \omega 9 c$, iso- $\mathrm{C}_{15: 0}$, iso$\mathrm{C}_{16: 0}$ and iso- $\mathrm{C}_{17: 0}$. The DNA $\mathrm{G}+\mathrm{C}$ content of the type strain is $67.0 \mathrm{~mol} \%$.

The type strain, JS12-10 $0^{\mathrm{T}}\left(=\mathrm{KACC} 12747^{\mathrm{T}}=\mathrm{JCM} 15423^{\mathrm{T}}\right)$, was isolated from forest soil taken from Jeju island, Republic of Korea.

\section{Description of Dyella terrae sp. nov.}

Dyella terrae (ter'rae. L. gen. n. terrae of the soil).

Cells are Gram-negative, aerobic, rod-shaped, 0.4-0.5 $\mu \mathrm{m}$ wide and 1.0-5.0 $\mu \mathrm{m}$ long, and motile with one polar flagellum. After growth on R2A medium at $28{ }^{\circ} \mathrm{C}$ for 2 days, colonies are yellow and irregular. Grows well on R2A agar, nutrient agar, tryptic soy agar and MacConkey agar. Positive for methyl red test and negative for nitrate reduction, Voges-Proskauer, $\mathrm{H}_{2} \mathrm{~S}$ production and phenylalanine deaminase. Grows at $10-35{ }^{\circ} \mathrm{C}$ (optimum $28-$ $30{ }^{\circ} \mathrm{C}$ ), $\mathrm{pH} 4-9$ (optimum $\mathrm{pH}$ 6-7) and $0-3 \%(\mathrm{w} / \mathrm{v}) \mathrm{NaCl}$ (optimum 0-1\%). DNA and tyrosine are hydrolysed, Tween 80 is weakly hydrolysed, but casein, chitin, CMcellulose, pectin, starch and xanthine are not. Weakly positive for $\beta$-galactosidase, but negative for indole production, glucose fermentation, arginine dihydrolase, urease, aesculin hydrolysis and gelatin hydrolysis (API 20NE). In addition to the data shown in Table 1, sodium acetate, L-serine and 3-hydroxybutyric acid are assimilated, but L-rhamnose, D-ribose, inositol, sucrose, itaconic acid, suberic acid, sodium malonate, lactic acid, L-alanine, potassium 5-ketogluconate, glycogen, 3-hydroxybenzoic acid, salicin, melibiose, L-fucose, D-sorbitol, propionic acid, valeric acid, L-histidine, potassium 2-ketogluconate, 4-hydroxybenzoic acid and L-proline are not (API ID 32 $\mathrm{GN})$. Major fatty acids $(>5 \%)$ are iso- $\mathrm{C}_{16: 0}$, iso- $\mathrm{C}_{17: 1} \omega 9 c$, iso- $\mathrm{C}_{15: 0}$, summed feature 3 (iso- $\mathrm{C}_{15: 0} 2-\mathrm{OH}$ and/or $\mathrm{C}_{16: 1}(\omega 7 c)$, iso- $\mathrm{C}_{11: 0} 3-\mathrm{OH}$ and iso- $\mathrm{C}_{17: 0}$. The DNA $\mathrm{G}+\mathrm{C}$ content of the type strain is $64.0 \mathrm{~mol} \%$.

The type strain, JS14- $6^{\mathrm{T}}\left(=\mathrm{KACC} 12748^{\mathrm{T}}=\mathrm{JCM} 15424^{\mathrm{T}}\right.$ ), was isolated from soil cultivated with Citrus species on Jeju island, Republic of Korea.

\section{Acknowledgements}

This work was supported by a grant (no. 20080401034028) from the BioGreen 21 Program, Rural Development Administration, Republic of Korea. 


\section{References}

An, D. S., Im, W. T., Yang, H. C., Yang, D. C. \& Lee, S. T. (2005). Dyella koreensis sp. nov., a $\beta$-glucosidase-producing bacterium. Int J Syst Evol Microbiol 55, 1625-1628.

Ausubel, F. M., Brent, R., Kingston, R. E., Moore, D. D., Seidman, J. G., Smith, J. A. \& Struhl, K. (editors) (1987). Current Protocols in Molecular Biology. New York: Wiley.

Breznak, J. A. \& Costilow, R. N. (1994). Physiological factors in growth. In Methods for General and Molecular Bacteriology, pp. 137154. Edited by P. Gerhardt, R. G. E. Murray, W. A. Wood \& N. R. Krieg, Washington, DC: American Society for Microbiology.

Dauga, C. (2002). Evolution of the gyrB gene and the molecular phylogeny of Enterobacteriaceae: a model molecule for molecular systematic studies. Int J Syst Evol Microbiol 52, 531-547.

Felsenstein, J. (1981). Evolutionary trees from DNA sequences: a maximum likelihood approach. J Mol Evol 17, 368-376.

Felsenstein, J. (1985). Confidence limits on phylogenies: an approach using the bootstrap. Evolution 39, 783-791.

Fitch, W. M. (1971). Toward defining the course of evolution: minimum change for a specific tree topology. Syst Zool 20, 406-416.

Johansen, J. E., Binnerup, S. J., Kroer, N. \& Mølbak, L. (2005). Luteibacter rhizovicinus gen. nov., sp. nov., a yellow-pigmented gammaproteobacterium isolated from the rhizosphere of barley (Hordeum vulgare L.). Int J Syst Evol Microbiol 55, 2285-2291.

Jung, H. M., Ten, L. N., Kim, K. H., An, D. S., Im, W. T. \& Lee, S. T. (2009). Dyella ginsengisoli sp. nov., a novel bacterium isolated from soil of a ginseng field in South Korea. Int J Syst Evol Microbiol 59, 460-465.

Kim, B. Y., Weon, H. Y., Lee, K. H., Seok, S. J., Kwon, S. W., Go, S. J. \& Stackebrandt, E. (2006). Dyella yeojuensis sp. nov., isolated from greenhouse soil in Korea. Int J Syst Evol Microbiol 56, 2079-2082.

Kimura, M. (1983). The Neutral Theory of Molecular Evolution. Cambridge: Cambridge University Press.

Kumar, S., Tamura, K. \& Nei, M. (2004). MEGA3: integrated software for molecular evolutionary genetics analysis and sequence alignment. Brief Bioinform 5, 150-163.

Leblond-Bourget, N., Philippe, H., Mangin, I. \& Decaris, B. (1996). $16 \mathrm{~S}$ rRNA and $16 \mathrm{~S}$ to $23 \mathrm{~S}$ internal transcribed spacer sequence analyses reveal inter- and intraspecific Bifidobacterium phylogeny. Int J Syst Bacteriol 46, 102-111.

Lee, D. W. \& Lee, S. D. (2009). Dyella marensis sp. nov., isolated from cliff soil. Int J Syst Evol Microbiol 59, 1397-1400.

Mergaert, J., Cnockaert, M. C. \& Swings, J. (2002). Fulvimonas soli gen. nov., sp. nov., a $\gamma$-proteobacterium isolated from soil after enrichment on acetylated starch plastic. Int J Syst Evol Microbiol 52, 1285-1289.

Mesbah, M., Premachandran, U. \& Whitman, W. B. (1989). Precise measurement of the $\mathrm{G}+\mathrm{C}$ content of deoxyribonucleic acid by highperformance liquid chromatography. Int J Syst Bacteriol 39, 159-167.

Nalin, R., Siomonet, P., Vogel, T. M. \& Normand, P. (1999). Rhodanobacter lindaniclasticus gen. nov., sp. nov., a lindane-degrading bacterium. Int J Syst Bacteriol 49, 19-23.

Reasoner, D. J. \& Geldreich, E. E. (1985). A new medium for the enumeration and subculture of bacteria from potable water. Appl Environ Microbiol 49, 1-7.

Saitou, N. \& Nei, M. (1987). The neighbor-joining method: a new method for reconstructing phylogenetic trees. Mol Biol Evol 4, 406425.

Sasser, M. (1990). Identification of bacteria by gas chromatography of cellular fatty acids, MIDI Technical Note 101. Newark, DE: MIDI Inc.

Seldin, L. \& Dubnau, D. (1985). Deoxyribonucleic acid homology among Bacillus polymyxa, Bacillus macerans, Bacillus azotofixans, and other nitrogen-fixing Bacillus strains. Int J Syst Bacteriol 35, 151-154.

Smibert, R. M. \& Krieg, N. R. (1994). Phenotypic characterization. In Methods for General and Molecular Bacteriology, pp. 607-654. Edited by P. Gerhardt, R. G. E. Murray, W. A. Wood \& N. R. Krieg. Washington DC: American Society for Microbiology.

Swings, J., Gillis, M., Kersters, K., De Vos, P., Gosselé, F. \& De Ley, J. (1980). Frateuria, a new genus for "Acetobacter aurantius". Int J Syst Bacteriol 30, 547-556.

Thompson, J. D., Higgins, D. G. \& Gibson, T. J. (1994). CLUSTAL W: improving the sensitivity of progressive multiple sequence alignment through sequence weighting, position-specific gap penalties and weight matrix choice. Nucleic Acids Res 22, 4673-4680.

Wayne, L. G., Brenner, D. J., Colwell, R. R., Grimont, P. A. D., Kandler, O., Krichevsky, M. I., Moore, L. H., Moore, W. E. C., Murray, R. G. E. \& other authors (1987). International Committee on Systematic Bacteriology. Report of the ad hoc committee on reconciliation of approaches to bacterial systematics. Int J Syst Bacteriol 37, 463-464.

Weisburg, W. G., Barns, S. M., Pelletier, D. A. \& Lane, D. J. (1991). 16S ribosomal DNA amplification for phylogenetic study. J Bacteriol 173, 697-703.

Weon, H. Y., Kim, B. Y., Kwon, S. W., Park, I. C., Cha, I. B., Tindall, B. J., Stackebrandt, E., Trüper, H. G. \& Go, S. J. (2005). Leadbetterella byssophila gen. nov., sp. nov., isolated from cotton-waste composts for the cultivation of oyster mushroom. Int J Syst Evol Microbiol 55, 2297-2302.

Xie, C. H. \& Yokota, A. (2005). Dyella japonica gen. nov., sp. nov., a $\gamma$ proteobacterium isolated from soil. Int J Syst Evol Microbiol 55, 753756. 